Др СОЊА ЈЕРКОВИЋ, научни сарадник Народна банка Србије Краља Петра 12, Србија, Београд Е-адреса: sonja.jerkovic@nbs.rs

\title{
РАЗВОЈ ВАЛУТНИХ ПРИЛИКА У КРАЉЕВИНИ СРБИЈИ (1884-1914)
}

\begin{abstract}
САЖЕТАК: У раду се анализира развој новчаних односа у Краљевини Србији, кроз оснивање Привилеговане Народне банке Краљевине Србије 1884. године и увођење у промет папирног новца. Питање подлоге, злато или сребро, још више се актуелизовало 1885. године увођењем новчанице од 10 динара са подлогом у сребру. Пораст ажије као доплате при замени за новац са златном подлогом довела је до оптужби државе да је емисиони завод прекомерним оптицајем новчаница у сребру заслужан за њен пораст. Међутим, како се показало, несређене политичке и привредне прилике у Краљевини Србији, недостатак капитала у претежно аграрној земљи такође су допринели напуштању првобитне идеје о монометализму - издавању новчаница на основу подлоге у злату.

КљУЧНЕ РЕЧИ: Народна банка, биметализам, ажија, папирни новац, политичке и привредне прилике
\end{abstract}

Деценије постепеног ослобађања од османске власти, поред изградње политичке аутономије, донеле су Кнежевени Србији и привредни полет који се огледао и у расту трговинског биланса и повећању новчаног промета. Без сопственог новца, у оптицају се налазио не само турски него и аустријски новац. Мноштво кованог новца, углавном од злата и сребра, али и од других легура, различите вредности стварало је проблеме приликом свакодневних плаћања. У намери да потврди своју аутономију и искује сопствени новац али саобразно међународним стандардима први ковани новац у апоенима од 1, 5 и 10 пара био је бакарни и појавио се у промету почетком 1869. године. Упоредо, Кнежевина Србија је настојала да се укључи и у европске токове и утврди паритет домаће валуте. Законом о ковању српске сребрне монете $1873 .{ }^{1}$ новчани систем се развијао и као новчана јединица се уводи динар.

${ }^{1}$ Сви датуми су навођени по новом календару. Срйске новине, бр. 267, 7/19. децембар 1873. 
Такође, усвајају се и правила Париске новчане конвенције из 1865. којом су уједначене вредности, тежина и величина сребрног и златног новца. ${ }^{2}$ Практично и фактички прихваћен је систем двојног важења метала, злата и сребра (биметализам) који се у Француској примењивао од 1803. Ова конвенција одредила је и однос вредности сребра према вредности злата 1:15,5 без обзира на кретања на тржишту.

Управо када је у Кнежевини усвојен закон о ковању сребрног новца на европском тржишту долази до промене односа између ова два племенита метала те европске земље настоје да ограниче или потпуно укину ковање сребрног новца све у циљу да се спречи чување „доброг” златног и повећање оптицаја оног другог сребрног „лошијег” новца. ${ }^{3}$ У годинама које су следиле док су чланице Латинске уније тежиле да уведу монометализам, у Србији све до оснивања емисионог завода на новчаном тржишту појавио се ковани новац разних апоена и од различитих врста метала. ${ }^{4}$

\section{ОСНИВАЬЕ ЕМИСИОНОГ ЗАВОДА}

Идеја о оснивању емисионог завода постепено се уобличавала током друге половине XIX века. У претежно аграрној Србији недостатак капитала погађао је и трговачки слој али и сељаштво које није имало других опција него да у недостатку новца потегне за позајмљивањем код зеленаша, уз огромну камату. Ни држава али ни богати слојеви нису имали јасну слику о томе какав је банкарски систем потребан Србији. Послови шпекулативног карактера, непознавање банкарских вештина, уска регионална омеђеност карактеристика су пословања приватних новчаних завода све до појаве Београдске задруге 1882. године. С друге стране, као државно чедо, Управа фондова није делала на општу добробит, него се дешавало да се, услед недостатка контроле кредитирања, кредити подигнути у Београду пласирају у унутрашњост са неколико пута већом каматом. Такође, идеја о томе каква би функција Народне банке била није била сасвим јасна. Свакако сви су у први план истицали њену кредитну функцију, док се о емисионој није толико полемисало. 5 Поред дилема о самој функцији Народне банке, постављало се и питање капитала. Наиме, од 1875, када је Народној скупштини поднет предлог статута „Књажевске српске повлашћене банке”, све владе, прво либералске а потом и напредњачке, биле су ближе идеји да неко друштво из иностранства уложи свој капитал у оснивање. Крах Генералне уније 1882.

\footnotetext{
2 Конвенцију су потписале и основале Латинску унију Француска, Белгија, Италија и Швајцарска, а четири године касније придружила им се и Грчка. Србија није формално приступила унији али се придржавала назначених правила. Dragana Gnjatović, „Kneževina Srbija na putu ka evropskim monetarnim standardima”, Bankarstvo 2 (2015), 12-33.

3 Јован Хаџи-Пешић, Новаи Србије 1868-1918, Народна банка Југославије, Београд 1995.

4 До издавања папирне новчанице од 100 динара 1884. у промету су се појавии сребрни новац у апоенима од 50 пара 1 и 2 динара, 1875. године, бакарни од 5 и 10 пара, сребрни од 50 пара, 1, 2 и 5 динара и златни у апоену од 20 динара 1879. године, 10 и 20 динара у злату 1882. године и новац од никла од 5, 10 и 20 пара 1883. године Ј. Хаџи-Пешић, н. д.

${ }^{5}$ Соња Р. Јерковић, Нарояна банка Краљевине Срба, Хрвайа и Словенаиа / Јуйославије 1918-1931, (докторска дисертација у рукопису, одбрањена 2018. на Одељењу за историју на Филозофском факултету у Београду).
} 
само је учврстио ставове у првом реду београдских привредника као носиоце трговине са суседном Аустроугарском да се Народна банка мора основати домаћим капиталом. Будући да краљ Милан и његови саветници нису веровали у ову идеју, Закон је оставио питање порекла капитала нерешено.

Закон о Народној банци из јануара 1883. је, поред основног задатка који се односио на кредитирање привреде, услед недостатка капитала емисионом заводу доделио и обавезу и привилегију издавања новчаница за државне потребе. Закон је предвидео штампање папирног новца у апоенима од 50, 100, 500 и 1000 динара са напоменом: „Народна банка дужна је да сваку своју банкноту размени у злато по пуној вредности и без икаквих одбитака чим се њезиној каси поднесе и таква размена затражи". ${ }^{6}$ На овај начин потврђена су настојања државе да се у Србији успостави систем златног важења валуте - монометализам.

Нема сумње да је оснивање емисионог завода представљало још један корак у даљој европеизацији Србије, али је, како се показало, почетак рада био скопчан са многим проблемима који су били страни и управи Банке и надлежном министарству народне привреде. Након отварања шалтера и отпо-

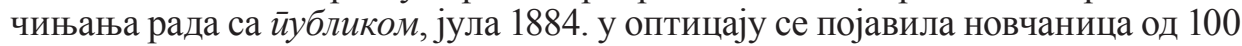
динара. ${ }^{7}$ Међутим показало се да становници Србије, чак и најбогатији слој трговаца, нису имали поверење у папирни новац. Новчаница није циркулисала него се одмах замењивала за звечећи златни новац, и тако су се банчини трезори празнили златним а пунили папирним новцем. Оно што је посебно забрињавало била је чињеница да су новчаницу одбијали да приме не само физичка лица приликом неке наплате него и финансијске институције (царинарнице, железничке благајне) а посебно Управа фондова са образложењем „да би јој то задавало исувише много посла”. ${ }^{8}$ Изгледа да „папирни” новац није био омиљен у пословању него се и даље у складу са начелима оријенталне трговине радије пословало са кованим новцем, нарочито са аустријским дукатима. Самим тим, не треба да чуди и велико неповерење грађана које је по Шарлу Бошману „доста разумљиво код једног народа који је за педесет година видео много ратова и револуција и где је постало уобичајено да се новац скрива". 9 Такође, стране дипломате су примећивале да је становништво „недовољно цивилизовано” да би прихватило домаћи папирни новац. ${ }^{10}$

${ }^{6}$ Срйске новине. бр. 13, 19/31. јануар 1883.

7 Коришћена је резервна новчаница Белгијске народне банке од 100 франака. Банкнотни цртежи штампани су у штампарији Белгијске народне банке у Бриселу на хартији са водотиском која је била припремљена за новчанице из 1876, док су бројеви, серије, датум издања и контролни број отискивани у Београду заједно са потписом гувернера и једног члана управе, све у присуству владиног комесара, Ј. Хаџи-Пешић, н. д., 96.

8 Архив Народне банке Србије (АНБ) 1/I, „Историјска архива”, архивска кутија (а.к.) 1 - део фонда у поступку архивистичког сређивања и обраде; у даљем тексту: АНБ 1/I., Писмо Управе фондова Министру народне привреде, 15. септембра 1884.

${ }_{9}^{9}$ АНБ, Збирка репродукованих материјала (25), Народна банка Белгије 1883-1886 (2). Репродукција из досијеа Народне банке Белгије под називом Misssion de Mr Boschmans á Belgrade 1884/1885. АНБ, 25-2, На захтев Србије из Белгије је као стручна помоћ упућен Шарл Бошман, шеф рачуноводства Народне банке Белгије, фебруара 1884.

10 John Robert Lampe, Financial structure and the economic development of Serbia, 18781912, University of Wisconsin, 1971. (докторска дисертација у рукопису чува се у Библиотеци Народне банке Србије), 123. 
Осврћући се на свој рад у првој години пословања управни одбор је наводио да су нейријайељски однос према новчаници заузели баш они „чијим је интересима управо била и намењена и који би већ из саобраћаја са иностранством морали познавати и основе на којима она почива и својство њено и важност и корист њену". 11 У ствари трговци нису при покретању банке имали у виду њен емисиони карактер, него су очекивали да она својим средствима помогне њихову трговину, убрза циркулацију новца, увећа понуду кредита на тржишту. ${ }^{12} \mathrm{O}$ исплати дивиденде није могло бити речи а и забележен је само мали број новчаних операција. Алекса Спасић, први гувернер, ову дужност је обављао током седам месеци 1884, када је поднео оставку13. Управа је желела да нови гувернер буде Чедомиљ Мијатовић али је он понуде упорно одбијао. ${ }^{14}$

Почетак рада емисионог завода одвијао се у сложеним и политичким и привредним приликама. Победа радикалне странке на изборима септембра 1883, распуштање Народне скупштине, избијање Тимочке буне, увођење ванредног стања у Црноречком округу, почетак рада преког суда. Након Тимочке буне влада односно краљ су законима тежили да утврде ауторитет власти. ${ }^{15}$ На то се надовезала и немоћ државе да управља својим финансијама, Повећани расходи захтевали су потрагу за већим приходима, који су се остваривали увођењем нових такси и пореза. Како ни то није било довољно држава је у периоду од 1881. до 1884. поред лутријског закључила још три зајма: за изградњу железнице, решавање аграрног питања и тзв. златну ренту и тиме се нашла у зачараном кругу новог задуживања због отплате пристиглих дугова.

\section{НОВЧАНИЦА ОД 10 ДИНАРА}

У таквој сложеној ситуацији почетком октобра 1884. на седницама управног одбора Народне банке разматрано је питање циркулације новчанице а са проблемом је био упознат и Милутин Гарашанин као председник владе којем су Ђорђе Вајферт, вицегувернер, и Шарл Бошман „објаснили и усмено све незгоде банчине" око недостатка ситнијих банкнота. ${ }^{16}$

Овај проблем отварао је два питања: прво, велику вредност новчанице а друго питање њене подлоге. Већ средином октобра управни одбор је раз-

11 Привилеїована Нарояна банка Краљевине Србије, Извешйај за 1884, Београд 1885, 12.

12 Истиорија Беоїраgа, књига 2, Просвета, Београд 1974, 421.

13 Алекса Спасић је био гувернер у периоду 8. март - 29. октобар 1884. а Филип Христић гувернер тек од 15. фебруара 1885. Привилеїована Народна банка Краљевине Србије, Извещйај за 1884, Београд 1885, 12.

${ }^{14}$ Мијатовић је у то време био шеф посланства Србије у Лондону. За гувернера је изабран Филип Христић (Београд, 1815 - Ментон, 1905), истакнута личност која је била министар у више ресора, пашеног Јована Ристића, гувернер је био од 1885-1890. Јелена Пауновић,

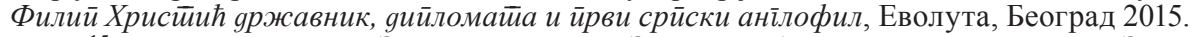

15 Измене и допуне у Закону о штампи, Закону о зборовима и удружењима, Закону о устројству општина, Слободан Јовановић, Влаgа Милана Обреновића, део II, Београдски издавачко-графички завод, Југославија публик, Српска књижевна задруга, Београд 1990, 204-206.

${ }_{16}$ АНБ1/І, Управа (УПР), Записници са седнице Управног одбора (УО), 9.10.1884, а. к. 1. 
говарао о потреби да се изда новчаница у вредности од 10 динара иако је та опција неизбежно водила измени Закона. И у наредним месецима постало је јасно да се стодинарка никако не задржава у оптицају, те је ово питање поново разматрано на седници управе децембра $1884 .{ }^{17}$ Након дугих дебата и конференција као општи закључак наметало се образложење да је раније у оптицају преовладавао ковани новац, као и да је новчаница од 100 динара исувише велике вредности с обзиром на обим размене, као и саме цене. ${ }^{18}$ Чланови управе, представници привредне елите престонице и Србије били су једниствени по питању измене Закона и увођења новчанице од 10 динара, међутим по питању њене подлоге дошло је до размимоилажења. ${ }^{19}$ Издавање динара са подлогом у злату требало је да потврди Збор акционара који је и сазван за март наредне, 1885. године. ${ }^{20}$ Пре одржавања Збора, своја одвојена мишљења објавили су Шарл Бошман и Илија Маргетић који су се, иако су били свесни колико је злато омиљено у српском народу „,ер га је лако носити и чувати", ипак залагали за сребро, јер су околне државе и, што је најважније, Аустроугарска имале у промету сребрни новац те би за српски емисиони завод било тешко да у обрту задржи новчанице на основу златне подлоге ${ }^{21}$ Сходно њиховом тумачењу било би угрожено кредитирање читаве привреде јер би Банка била принуђена да повећа своју каматну стопу. С друге стране Марко Стојановић и Коста Месаровић су били против указујући у првом реду на проблем ажије као и да новчаница са подлогом у сребру неће утицати да страни ковани новац нестане из оптицаја у Србији. ${ }^{22}$ Колико

17 Управу Народне банке чинили су гувернер, управни, контролни (надзорни) и главни одбор који су сачињавали чланови управног и надзорног одбора, збор акционара и есконтни одбор и вицегувернер који је биран из редова чланова Управног одбора. Чланови Управног одбора: Јово Крсмановић, Ђорђе Вајферт, Никола Рашић, Михајло Терзибашић, Јевта Павловић, Јован Антула, Марко Стојановић, Коста Месаровић и Милан Бранковић, сви из Београда; чланови Контролног одбора: Илија Маргетић, Манојло Клидис и Јаков Бајлони из Београда, Алекса Бајић из Шапца и Лазар Лазаревић из Ваљева.

18 У покушају да у оптицај уђе папирни новац, штампана је новчаница од 50 динара, фебруара 1885. и иако је по вредности била упола мања од прве банкноте није много допринела прихватању папирног новца у Србији, јер је и она била одвише крупна за новчани промет. J. Хаџи-Пешић, н. д., 122; зарада чиновника Народне банке на месечном нивоу била је у распону од 60 до 500 динара. Miodrag Ugričić, Novčani sistem Jugoslavije, Zavod za izdavanje udžbenika Socijalističke Republike Srbije, Beograd 1967, 71.

${ }^{19}$ Седници је присуствовало десет члнова, за десетицу у сребру су се изјаснили: Јаков Бајлони, Илија Маргетић, Манојло Клидис (накнадно је променио мишљење и изјаснио се за десетицу у злату), Михајло Терзибашић и Јово Крсмановић, а за златну подлогу: Коста Месаровић, Јован Антула, Никола Рашић, Ђорђе Вајферт и Марко Стојановић. Пошто је чланом 36 Статута било регулисано „да у случају једнаке поделе ілласова решава глас председника" а Ђ. Вајферт је као вицегувернер гласао за злато, „решено је да банкноте од 10 динара имају гласити на злато”. АНБ1/І, Управа (УПР), Записници са седнице Главног одбора (ГО), 30. децембар 1884, а. к. 16.

20 Предлог Главног одбора за измене и допуне Закона о Народној банци, Срйске новине, бр. 51 и $52,6 / 18$. и 7/19. март 1885.

21 Законом је утврђена повластица да може бити новчаница у циркулацији два и по пута више него што износи метална подлога. Срйске новине, бр. 13, 19/31. јануар 1883.

22 Архив Србије (АС), Министарство народне привреде, трговинско (МНП-Т), ПФ ІІІ, Рно 93/1897, Сва мишљења су објављена и у Срйским новинама у наставцима у периоду 8-12. марта 1885, с тим да се и Јован Антула изјаснио против сребра, а с обзиром да је био у иностранству његово мишљење није објављено. 
су оснивачи емисионог завода били различитих ставова по питању подлоге новчанице говоре и извештаји управног и надзорног одбора припремљени за збор акционара. Наиме док се у извештају управног одбора не помиње могућност издавања десетице у сребру, извештај надзорног одбора управо говори о непходности новчанице у сребру. ${ }^{23}$

Због недовољног броја пријављених акционара и акција збор је одложен за почетак априла када се у два дана дебатовало о издавању новчанице од 10 динара и њеној подлози. ${ }^{24}$ На крају другог састанка који је одржан 15. априла гласао је 241 акционар са 364 гласа за злато и 106 акционара са 159 гласова за сребро, што значи да је збор већином гласова решио да новчанице од 10 динара представљају вредност злата. ${ }^{25}$ Оно што посебно подвлачимо је да су збору присуствовали и министар народне привреде Драгослав Рајовић као и владин комесар при Народној банци Мита Ракић, као представници државе, и нису се оглашавали по овом питању, него су „обећали да ће измену Закона о Народној банци поднети првој Скупштини на решавање”. 26 Међутим то се није дешавало и Банка је била принуђена да изврши и редукцију чиновника, будући да су приходи једва подмиривали трошкове. Разлог томе треба тражити и у одржавању Народне скупштине у Нишу као и министарској кризи која је тињала још од лета 1884. године све до маја 1885.27 Друга влада Милутина Гарашанина, али без Стојана Новаковића, са Вукашином Петровићем као министром финансија је на изненађење управе Народне банке променила мишљење и саопштила ,да је Влада свагда била за десетицу, а и сада је за њу, не да буде у злату већ у сребру”. Узалудни су били напори Филипа Христића да и усменим путем убеди министарство да се прихвати измена закона јер је министар између осталог саопштио ,да Влада држи да ће банкноте од 10 динара у злату бити штетне по интересе банчине и народно економске прилике наше". ${ }^{28}$ Без обзира на одлуке збора акционара, министар је на Видовдан обавестио емисиони завод да ће предложити измене и допуне Закона о Народној банци само уколико новчаница од 10 динара буде имала подлогу у сребру. ${ }^{29}$ Разлоге за овај став треба тражити и у намерама државе да изда своју новчаницу на подлози Лутријског зајма из 1881. и тако још више угрози валутне прилике. ${ }^{30}$ Као вид притиска

23 Извештај су потписали Илија Маргетић и Јаков Бајлони, док је одвојено мишљење за десетицу у злату потписао Манојло Клидис Привилейована Нарояна банка Краљевине Србије, Извешйај за 1884, Београд 1885, 25-27.

24 У јавној дебати на Збору учествовали су између осталих Лука Ћеловић изјашњавајући се за сребро док су Михаило Вујић и Панта Срећковић заступали златну подлогу. Привилеїована Нарояна банка Краљевине Србије, Извещйај за 1885, Београд 1886, 42.

25 Сходно Закону одлуке су се доносиле већином гласова, при чему је 5 акција давало право на један глас, 15 на два гласа, 25 на три гласа све до 100 акција на седам гласова. Максимални број гласова био је лимитиран на 30 за шта је било потребно 560 акција. Нароgна банка 1884-1909, Штампарија Љуб. М. Давидовића, Београд 1909, 148-150.

26 Привилейована Нарояна банка Краљевине Србије, Извещй̄аj за 1885, Београд 1886, 42, Нарояна банка 1884-1909, 44.

27 С. Јовановић, Влаgа Милана Обреновића, 208-219.

28 АНБ1/І, УПР, Записници са седнице ГО, 27. јуна 1885, а. к. 16.

29 Такође, државна каса је била празна уочи рата са Бугарима, С. Јовановић, Bлаga Muлана Обреновића, 78-84.

30 Велик део ових обвезница које су гласиле на 100 динара у злату је остао непласиран, те је планирала да се на подлози ових обвезница издају вредносни папири који би гласили 
на емисиони завод током 80-их година XIX века изнова се обнављала идеја о издавању новчаница, без јасно утврђене норме о питању подлога као и о томе да ли ће то бити прави новац у циркулацији или ће само послужити за подмиривање државних потраживања. ${ }^{31}$

Да би колико-толико сачувала форму независне институције, управа је сазвала ванредни збор акционара који је требало да усвоји измену предлога Закона, али овог пута са десетицом у сребру. Нема сумње да су гувернер и чланови управе били уцењени јер су итекако били свесни да уколико у оптицају остане само новчаница од 100 динара то ће угрозити пословање Народне банке и иако су већином били за златну подлогу десетице, вероватно вођени и личним интересима, као мање зло изабрали су пре да буде са сребрном подлогом него да се уопште не штампа. ${ }^{32}$

Ванредни збор акционара одржан је 26. и 30. септембра 1885. када је акционарима предочено да се расправља о опстанку Народне банке. О предлогу се није дискутовало него је усвојен акламацијом. ${ }^{33}$

Само пет дана касније Народна скупштина у Нишу је усвојила предлог измена и допуна Закона о Народној банци у којем су најважније измене доживели чланови 9 и 10. У члану 9 додата је одредба о банкноти у вредности од 10 динара, док је у члану 10 измењена прва алинеја која је стављала у дужност централној банци да новчаницу од 10 динара размени у сребро, а оне од 50, 100,500 и 1000 динара у злато. ${ }^{34}$ Након усвајања Закона и неуспешног рата са Бугарском, који је још више повећао оскудицу новца, држава се потрудила да ова новчаница уђе у све домове и буде прихваћена као средство плаћања. ${ }^{35}$

У почетку, Банка је ову новчаницу називала „привременом”, не само због начина на који је пуштена у оптицај уз притисак државе него и због тога што је сматрала да је златна подлога за њене новчанице оно чему треба да теже Народна банка и сама Краљевина. ${ }^{36}$ Због тога је успех ове новчанице у народу прихваћене под именом „банка”, како ће се касније називати сви апоени у вредности од 10 динара, био неочекиван за емисиони завод.

\section{АЖИЈА И НАРОДНА БАНКА}

Тако је у Краљевини потврђен биметализам и због постојања новчаница у злату а и у сребру, приликом склапања уговора у пословном свету приме-

на 10 динара у злату; чак је такав предлог и поднет на разматрање Народној скупштини, која је распуштена пре него што је овај предлог разматрала. Указ и предлог закона о издавању десетица од лутријских обвезница, Сйеноіррафске белещке о раgу Нарояне скуйшимине за 1887. іоgину, Београд 1885, Састанак XII од 7. априла 1888. 912-915.

${ }^{31}$ Нарояна банка 1884-1909, 149.

32 АНБ1/І, УПР, Записници са седнице УО, 31. октобар 1885, а. к. 1.

33 Измена Закона се односила и на оснивање агенција као и на есконтовање вараната, Привилеіована Нарояна банка Краљевине Србије, Извещйај за 1885, Београд 1886, 49.

${ }^{34}$ Срйске новине, бр. 213, 27. септембар / 8. октобар 1885.

35 „Распис свим начелствима и царинарницама, министра финансија Вукашина Петровића да сваком приликом објашњују народу вредност и корист банкнота", Срйске новине, бр. 45, 26. фебруар / 9. март 1886.

36 AC, МНП-T, Ф VII, p 38/1891. И у дописима упућеним надлежном министарству Банка је „десетицу означавала као привремену”. 
њивала се тзв. „клаузула монете” као разлика између домаћег новца и злата којим су се измиривале међународне обавезе. У унутрашњем промету се однос између злата, сребрне новчанице и сребра увек успостављао рачунањем ажије, односно дисажије. ${ }^{37}$ Овај систем паралелне валуте, где је с једне стране постојала златна валута а с друге стране новчаница од 10 динара платива у сребру, утицао је на неке да наведу да предратни српски новчани „сустав” није добро функционисао. ${ }^{38}$ Наиме, због повећања производње сребра почев од 70-их година XIX века у Европи однос између сребра и злата поново се променио у корист злата које се вредновало као добар новац. Пораст ажије је био својеврстан показатељ опадања вредности националне валуте-динара у односу на злато као међународно признато средство плаћања. ${ }^{39}$

Од увођења ове новчанице њен оптицај је стално био у порасту те како је наводила Народна банка у промету је циркулисала само сребрна новчаница, циркулација златне новчанице тако је мала да се о златној новчаници као средству циркулације не може ни говорити. 40 Тако се деведесетих година XIX века јавило размишљање да она повећава ажију на злато. Појава ажије уносила је немир у све, у првом реду у трговачки свет али и међу обичне људе. У свим расправама са државом Банка је указивала да ажија искључиво расте услед недостатка злата којег има само када је сезона извоза. Као разлоге за пораст ажије емисиони завод је наводио рђаве економске прилике, мали извозни капацитет у то углавном сировина, велик увоз готових производа, уопште неуређеност државних финансија. Такође, као аргументи истицани су и државно задуживање и обавеза да се дуговања измирују у новцу са златном подлогом. Народна банка је била свесна да не може својим мерама учинити да ажија нестане, али је већ од 1890. настојала да спречи превелике флуктуације током године и то интервенцијама на тржишту углавном продајом златних наполеондора.

Посредно, питање сребрне новчанице је постало јабука раздора између емисионог завода и потоњих министара финансија све до избијања Првог светског рата. Наиме, Законом је било регулисано да у оптицају може бити

37 Ажија (agio) је износ за који једна врста новца прекорачује номиналну вредност односно додатак који се код плаћања у лошијем новцу (папир-злато) мора дати. Насупрот томе дисажија је износ који заостаје испод номиналне вредности односно одбитак који се узима код плаћања у бољем новцу. И ажија и дисажија су се изражавале у процентима. Нпр. златна ажија од 35\% значи да 100 јединица (динара) у злату јесу 135 јединица у папирном новцу а дисажија од 25\% да 100 јединица у папиру јесте 75 јединица у злату. Feliks Kohn, Trgovački i pravni leksikon, Osijek 1937, 13. Овај проблем је оптерећивао српске финансије и пре оснивања Народне банке и био је карактеристичан за све привредно неразвијене земље са спољним зајмовима с обзиром да се при исплати дуговања појављивала разлика између домаћег новца и новца којим су се морале измирити обавезе. У Краљевини Србији је добио на замаху са увођењем новчанице у сребру. У читавом периоду износ ажије је варирао и зависио је од многих фактора: приноса, извоза односно увоза, дефицита у буџету... Иако је у прво време Банка покушавала да откупом односно продајом злата утиче на умањење ажије ова мера се показала као неадекватна и додатно је поспешила разне шпекулације, тек са уравнотежењем буџета проблем ажије је знатно умањен. Нароgна банка 1884-1909, $155-161$.

38 Jozo Tomašević, Novac i kredit, Zadružna štamparija, Zagreb 1938, 151. $60-63$.

39 Верољуб Дугалић, Нароgна банка 1884-1941. Југословенски преглед, Београд 1999,

40 Нарояна банка 1884-1909, 48. 
два и по пута више новчаница у односу на металну подлогу при томе је злато могло бити замењено сребром највише за четвртину. ${ }^{41}$

У више наврата емисиони завод и ресор финансија су покушавали да дођу до заједничког договора око решавања овог питања које је оптерећивало српску привреду. У ту сврху оформљен је 1891. чак и заједнички одбор, ${ }^{42}$ али рад ове комисије који је трајао више од две године није довео до приближавања ставова. 43

Представници Владе у комисији су сматрали: „Народна банка издавањем сребрних новчаница на основи злата не само да ради против својих штатута и закона о Народној банци, не само да не одговара потпуно оној цељи за који је основана, већ тим својим радом штети интересе земље, народа и државе".44 Такође у јавности Банка је критикована да део оптицаја сребрних новчаница није употребљаван за кредитирање привреде него за куповину и продају злата. ${ }^{45}$ С друге стране Банка се правдала да то ради у циљу умањења флуктуације ажије и сузбијања шпекулације али је признавала ,да је тај посао доносио извесне користи". 46 Сасвим сигурно је у периоду 1890-1893. емисиони завод интервенцијама на тржишту покушавао да умањи пораст ажије али у томе није успео. Политичке прилике нису ишле на руку сређивању стања у финансијама. Радикалске владе које су добиле мандат на основу изборних резултата у целом периоду трећег Намесништва 1889-1893. покушавале су да смање буџетски дефицит док обновљени трговински уговор са Аустроугарском из 1892. није поправио однос трговинске размене. ${ }^{47}$

У међусобном оптуживању ко је крив за овај проблем ни Народна банка није била монолитна. Наиме 1891. и 1892. на редовним зборовима акционара чула су се мишљења мимо управе да Народна банка издаје сребрне новчанице у великој количини и да тиме не чини услуге трговини, односно да не поштује члан 11 Закона. ${ }^{48}$ Интересантно је да су ови акционари били представници либералне странке али и представници извозничког лобија у Београдској трговачкој комори. 49

41 Члан 11 закона, Срйске новине, бр. 213, 27. септембар / 8. октобар 1885.

42 Са предлогом су се сагласили и министри народне привреде и финансија Коста Таушановић и Михаило Вујић, Нарояна скуйщйина, службени лист о раду српске народне скупштине, бр. 132, 21. април 1891.

43 Чланови Владине комисије: Димитрије Стаменковић, Мијајло Поповић, начелник Министарства финансија, и Јован Бошковић, комесар Народне банке, чланови комисије Народне банке: Марко Стојановић и Никола Рашић, чланови Управе и Бранко Бошковић, директор Банке, АС, МНП-Т, ф V, 72/96.

44 Исто, Извештаји чланова комисије.

45 Злато се гомилало у трезорима и коришћено је за исплату дивиденде акционарима,

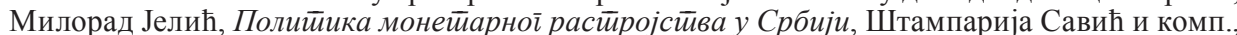

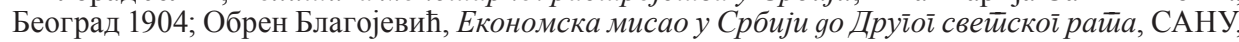
Београд 1980, 356-357.

46 Народна банка 1884-1934, Завод за израду новчаница - Топчидер, Београд 1934, 34.

47 Сузана Рајић, Данко Леовац, Истиорија срйской нароga у 19. и йочейком 20. века, Завод за уџбенике, Београд 2018, 246-251.

48 За то су се нарочито залагали: Коста Ризнић, Тодор Мијаиловић, Петар Јовановић, Влада Чортановић, Милан Маринковић, Нароgна банка 1884-1909, 159.

49 У овом периоду многобројна трговачка удружења су се обраћала Народној банци са молбом „да поради на сузбијању ажије”, Нарояна банка 1884-1909, 160; Василије Крестић, 
Упркос противљењу управе и без сагласности збора акционара, држава је покушавала да сама реши ово питање. Краљ Александар Обреновић је у свом обраћању посланицима новембра 1893. напоменуо да је њихов најважнији посао да раде на сређивању финансијских прилика у земљи. ${ }^{50}$ Тако је у Народној скупштини изгласан и Закон о изменама и допунама Закона о Народној банци децембра 1893. ${ }^{51}$ Приликом усвајања измена Народна банка је означена као главни кривац за пораст ажије и критикована је због увођења сребрне новчанице која је, како се сматрало, била плод напредњачког режима под којим је настало и највеће задуживање у иностранству. 52

Измена Закона је значила да је предвиђена подлога у злату служила само за новчанице које гласе на злато, а да је подлога у сребру за новчанице које гласе на сребро.53 Ђорђе Вајферт је као гувернер обавестио министарство народне привреде о неслагању са усвојеним изменама. ${ }^{54}$ Међутим, без обзира на своје неслагање Банка је тражила инструкције како да поступи и како да практично спроведе ове измене. Наиме у оптицају је било далеко више новчаница у сребру него што је било сребра у трезорима. Постојале су две могућности: или да се продајом злата набави сребро за покриће оптицаја или да се оптицај умањи у складу са стањем у трезору. С обзиром да је влада Саве Грујића била за неку врсту дефлационе политике, одлучила је да се у року од пет година изврши постепено смањивање сребрних новчаница у оптицају. ${ }^{55}$ Међутим ова намера није спроведена у дело; криза парламентаризма, суспендовање Устава из 1889. и враћање устава из 1869. само су скренули пажњу са финансијских и привредних потешкоћа. ${ }^{56}$ Банка се послужила опробаним средством притиска на државу и заузела став да се смањивање оптицаја може извршити једино редукцијом кредита, те је октобра 1894. обавестила све новчане заводе да ће обим кредита умањити за 20 процената. Са овим се поклопила и лоша привредна ситуација: „Кукуруз

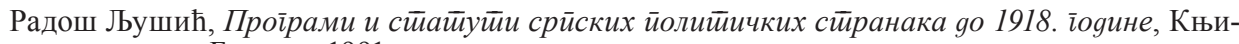
жевне новине, Београд 1991.

50 Мирослав Д. Пешић, Божица Б. Младеновић, „Криза парламентарног система у Краљевини Србији од 1892. до 1894. године”, Истиоријски часойис, књ. LXVI (2017), 401-435.

${ }^{51}$ Срйске новине, бр. 283, 18/30. децембар 1893.

52 По мишљењу радикалске владе и њеног министра финансија Вујића сребрне новчанице Народне банке, ако нису биле једини биле су главни узрок ажије. Слободан Јовановић, Влаgа Алексаняра Обреновића, део I, Београдски издавачко-графички завод, Југославија публик, Српска књижевна задруга, Београд 1990, 205.

53 Као покушај даљег утемељења златног важења овим изменама додата је и одредба да Народна банка може убудуће издавати и новчанице од 20 динара у злату.

54 „Кад се данас једнострано може у повластици један члан дописати, други заменити трећи истумачити сасвим другачије него што је годинама и од стране државе и од стране повлашћеног завода тумачен и словом и делом, онда ко може веровати да та судбина неће сутра постићи и сваки други члан из те повластице, а и сваку другу повластицу?” АС, МНП-Т, ф V, 72/96, Писмо бр. 14711, 21. децембар 1893. Након Филипа Христића, 1890. за гувернера је потврђен Ђорђе Вајферт, који је на тој функцији остао до 1902. Саша Илић, Соња Јерковић, Владимир Булајић, Ђорђе Вајферй, визионар и йреїалащ, Народна банка Србије, Београд 2012.

55 AC, МНП-Т, ф V, 72/96, План Владе је био да на крају пете године оптицај износи 10 милиона које би одговарало покрићу од 4 милиона (40\%).

56 Сузана Рајић, „Примена парламентаризма у Србији (1889-1894)”, Беоіраgски истиоријски іласник I, 2010, (2011), 137-166. 
којим се већи део нашег народа рани родио је рђаво. Шеница и шљиве ти важни предмети наше извозне трговине нису скоро имали тако слабу тражњу и тако ниску цену као прошле године". ${ }^{57}$ Оба министарства, и финансија и народне привреде, била су претрпана захтевима новчаних завода да се ова банчина одлука не спроведе. Министар Сима Лозанић је сматрао да „оваквим начином извођења поменутог закона значи лечити зло горим". ${ }^{58}$ Када се дода да је Банка такође морала да престане да купује и продаје злато због интервенције на новчаном тржишту у циљу смањења ажије, онда није ни чудо да је у том периоду ажија достигла највиши ниво. ${ }^{59}$ Већ новембра 1894. министар народне привреде је тражио да се опозове Банчина одлука о смањењу кредита, упозоравајући на лоше привредне прилике у земљи. Такође, и следеће, 1895. министарство је поновило захтев са назнаком: „да са погледом на неповољне економске прилике у којима се земља налази наредио Управном одбору да и сада не приступа послу око повлачења новчаница". 60

Ово натезање и свакако нерегуларно стање добило је свој епилог у изменама и допунама Закона од 18. фебруара 1896. Наиме на иницијативу Народне скупштине поново је враћена стара пракса да подлога за сребрне новчанице може бити у оба племенита метала са ограничењем броја сребрних новчаница на 25 милиона. ${ }^{61}$ Напредњачка влада Стојана Новаковића је овим изменама била предусретљива према емисионом заводу који је требало да оперативно спроводи одредбе карлсбадског аранжмана, а с обзиром на економску снагу Србије, сервисирање страних зајмова је свакако био захтеван задатак. ${ }^{62}$ Ђорђе Вајферт је као гувернер био упознат са лошим стањем државних финансија и као члан српске делегације учествовао је у завршним преговорима у бањи Карлсбад. ${ }^{63}$

Један од најжешћих критичара емисионог завода био је и Михаило Вујић, министар финансија у другој влади Ђорђа Симића, који је сматрао да Банка „не може више издавати сребрне новчанице на основу подлоге у злату, а нарочито још куповином домаћег злата посредством самих сребрних новчаница већ само на основу подлоге у сребру". ${ }^{4}$ Није само Вујић оптуживао емисиони завод да је златно важење новчаница мртво слово на папиру и да је и златно покриће претворила у сребрно, него су се почетком двадесетог века појавиле брошуре које су постављале питање треба ли Народној банци

57 Привилеїована Нарояна банка Краљевине Србије, Извещйај за 1894, Београд 1895, Х. бра 1894.

58 AC, МНП-Т, ф V, 72/96, Писмо министра Народне привреде П. бр. 4.168 од 17. окто-

59 Ажија је износила 19\%, Нароgна банка 1884-1934, 34. Branko Hinić, Milan Šojić, Ljiljana Đurđević, „Monetary conditions in the Kingdom of Serbia (1884-1914)”, Economic and Financial Stability in SE Europe in a Historical and Comparative Perspective (Fourth Annual Conference of South-Eastern European Monetary History Network). Belgrade: National bank of Serbia, 2009.

60 Привилеіована Нарояна банка Краљевине Србије, Извещйај за 1895, Београд 1896, XII.

${ }^{61}$ Срйске новине, бр. 36, 16/28. фебруар 1896.

62 Dragana Gnjatović, Stari državni dugovi Prilog ekonomskoj i političkoj istoriji Srbije i Jugoslavije 1862-1941, Ekonomski institut, Jugoslovenski pregled, Beograd 1991.

63 Бошко Мијатовић, „Конверзија српских дугова: Карлсбадски аранжман 1895. године”, Годищњак за ярущйвену истиорију 3, 2012 (2013), 43-63.

64 Михаило Вујић, Начела нароgне економије, књига друга - економска теорија, Државна штампарија Краљевине Србије, Београд 1896, 138-145. 
продужити повластицу на још 25 година јер је њена политика главни узрок појаве ажије. 65 Такође напредњачке владе су апострофиране као главни кривац за кршење Закона о српским народним новцима из 1878. и правила Латинске уније. ${ }^{66}$ Ова догађања треба посматрати у контексту сређивања државних финансија, када је министар Вујић покушавао да изврши конверзију српских дугова, али без успеха. ${ }^{67}$

У периоду од 1898. до 1900. године чак три пута је мењан закон о Народној банци а забележен је и највећи пораст ажије. 68 Увек без пристанка емисионог завода јер се показало да ограничење оптицаја сребрних новчаница значи смањење кредитирања привреде. Али главни проблем је свакако био задуживање државе која је услед личног режима краља Александра Обреновића и честих политичких криза било да је у питању распуштање Народне скупштине, повратак краља Милана у Србију, ивањдански атентат или захтев Русије да Србија измири своја дуговања, посезала за ванредним кредитима код Народне банке. ${ }^{69}$ Лоше државне финансије су представљале и проблем влада Михаила Вујића 1901/1902. године које су задуживањем настојале да одложе државно банкротство. ${ }^{70}$ Корак ка сређивању финасија свакако је представљало склапање тзв. Монополског зајма којим се Краљевина ослободила ,летећег” дуга. ${ }^{71}$

Након 1904. српске финансије улазе у мирније воде те се то итекако одражава и на кредитни однос између државе и емисионог завода, сходно ставу министра финансија Лазе Пачуа „да Народна банка не треба да буде извор за појачање државних прихода". 72 Део износа зајма склопљеног у Француској искоришћен је и за смањивање дуга емисионом заводу. Међутим, питање ограничења оптицаја новчаница у сребру и даље је било камен спотицања између емисионог завода и радикалске већине која је у њему видела бастион извозничког лобија који је повезан са династијом Обреновић и напредњачком идеологијом. ${ }^{73}$

Преговори око продужења повластице која је била дата на 25 година, дакле истицала је 1908, били су прилика да се изврши притисак и да се још једном подвуче незадовољство државе због неуплаћеног капитала, отварања филијала, али и ограничавања оптицаја новчаница у сребру. ${ }^{74} \mathrm{C}$ обзиром да је постојала обострана сагласност да се повластица може продужити, након

65 Сходно првом закону о Народној банци, емисиони завод је повластицу од државе добио на 25 година које су истицале 1908. М. Јелић, н. д.

66 Исто.

67 Бошко Мијатовић, н. д., 43-63.

68 Срйске новине, бр. 66, 22. март / 2. април 1898; Срйске новине, бр. 162, 28. јул / 8. август 1898, Срйске новине, бр. 191, 25. август / 5. септембар 1900.

69 Износ државног дуга је крајем 1898. износио око 15,9 милиона и био два пута већи од целокупног ранијег задужења, Нароgна банка 1884-1934, 36, 38; АНБ 1/I, УПР, Записници са седница Управног одбора, март/април 1898, а.к. 13.

70 Сузана Рајић, „Нова политичка заједница и владе Михаила Вујића 1901/1902. године", Исӣоријски часойис, књ. LX (2011), 505-539.

71 Dragana Gnjatović, Stari državni dugovi, 87.

72 Нарояна банка 1884-1934, 38.

73 J. Lampe, н.д., 173-210.

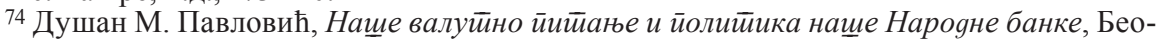
град 1908. 
дугих преговора и преписке око именовања представника Владе и Банке у комисију за израду закона, септембра 1906. формиран је ужи одбор који су сачињавали. Ђорђе Вајферт, Марко Стојановић, Милић Ј. Радовановић и Аца 3. Поповић.75 Почетак Царинског рата 1906. убрзао је преговоре али компромис је био постигнут тек неколико недеља пре истицања повластице. На инсистирање државе максимум контингента сребрних новчаница је ограничен на однос 5 према $1 .{ }^{76}$

Иако је у обраћању Државном Савету министра народне привреде Косте Стојановића детектован валутни проблем као најважнији он ни овим законом није решен. Наиме његово решавање се оставља повољнијим приликама „у ком ће случају Банка бити дужна да све банкноте на сребро претвори у банкноте на злато". ${ }^{77}$ По питању ажије иако је као кривац означавана Народна банка и држава је била свесна да се о овом питању може тек расправљати „кад се буде располагало већим суфицитом, када међународни биланс буде активан, када не буде било бојазни да ће се услед оскудице злата у земљи, моћи извући банчина златна подлога".78 Међутим, како се наводи у Споменици Народне банке, када су се у 1912. ове претпоставке оствариле у приличној мери вероватно да би тада дошло до прелаза на златно важење, да Србија није ушла у ратне заплете, који су својим седмогодишњим трајањем одгодили за дужи низ година дефинитивно решење валутног питања". 79

\section{ЗАКЉУЧАК}

Од увођења новчанице у сребру 1885. проблем ажије је значајно оптерећивао српску привреду. Како се наводи у Споменици Народне банке: „О узроцима ажије писано је и говорено можда више него о ма ком другом привредном проблему у периоду од 1893. до 1903. године када је она била највећа". 80 Покушај да се у промету одомаћи златна новчаница од 100 динара завршио се неуспехом. Препреку није представљала само величина апоена него и уверење да је злато као вреднији метал потребно тезаурисати. Наиме новчаница са подлогом у сребру је веома ретко замењивана за метал и као таква је била погодна за новчани оптицај. С једне стране она је погодно утицала на тадашњу основну функцију емисионог завода - кредитирање привреде и државе. У периоду до почетка Првог светског рата ова новчаница је учествовала са $95 \%$ у новчаној маси.

Поред мноштва добрих ствари, као што су већа циркулација и кредитирање привреде, увођење сребрног папирног новца у Србији имало је и лошу страну. Наиме док је привредно развијенији део западне Европе биметали-

75 АНБ1/І, Управа (УПР), Записници са седница Управног одбора, 1905-1906, а. к. 8. Ацу Поповића је заменио Марко С. Ђуричић.

76 „Оних банкнота, које гласе на сребро, редовно не може Банка издати више од пет пута онолико колико јој је уплаћен капитал”, Закон о продужењу повластице Народној банци, Срйске новине, бр. 69, 25. март / 6. април 1908.

77 Наровна банка 1884-1909, 199.

78 Изјава Косте Стојановића, Нарояна банка 1884-1934, 68.

79 Исто.

80 Нарояна банка 1884-1934, 39. 
стичког блока (Француска, Белгија, Швајцарска и Италија) настојао да се стандардизује вредност сребрног новца и ограничи његову понуду, Србија, односно њен емисиони завод је до Првог светског рата пустио у промет не само новчаницу од 10 динара него и од 100 динара плативу у сребру. ${ }^{81}$ Држава је била принуђена да своје приспеле ануитете по међународним зајмовима измирује у злату, немоћна да одржи конвертибилност динара.

Међутим и поред напада на емисиони завод да је једини одговоран за пораст ажије, која је у периоду од 1893. до 1903. била у сталном порасту, ипак се показало да су сређивање политичких прилика након промена династија, регулисање задуживања државе код Народне банке и у иностранству утицали и на валутне прилике.

У овом зачараном кругу међусобних оптужби ко је крив за пораст ажије одговор је да су за то заслужне обе стране: Народна банка је прекомерном емисијом новчаница на подлози сребра потискивала златну монету и манипулисала објашњењима и подацима колико се новчаница налазило у оптицају, док је држава утицала на пораст доплате у сребру дефицитом у платном билансу, честим задуживањем у иностранству, несређеним политичким приликама, у којима се посезало за кредитима код централне банке који су сервисирани управо новчаницама које нису имало одговарајуће покриће. На овај начин кредитна функција емисионог завода је била ослабљена јер се и тај капитал користио за кредитирање државе, а не привреде.

Потврда биметализма издавањем прво новчанице вредности 10 динара са подлогом у сребру утицала је на пораст ажије али се ова десетодинарка задржала у оптицају и учинила да папирни новац као средство плаћања буде опште прихваћен у Србији.

ORIGINAL SCIENTIFIC PAPER

SONJA JERKOVIĆ, PhD, research associate

National Bank of Serbia

Kralja Petra 12, Serbia, Belgrade

E-mail: sonja.jerkovic@nbs.rs

\section{DEVELOPMENT OF CURRENCY OPPORTUNITIES IN THE KINGDOM OF SERBIA (1884-1914)}

SUMMARY: The paper analyzes the development of currency opportunities since the introduction of the national currency - the dinar. With the establishment of the Privileged National Bank of the Kingdom of Serbia in 1884, as a joint stock company, the state intended to gradually find only gold-backed banknotes in circulation. However, unsettled political conditions, a poorly developed economy with a chronic lack of capital changed the original efforts. By issuing a 10 dinar banknote with a silver base in 1885 , bimetallism was confirmed in Serbia. This banknote soon entered the circulation and made up a large part of the money supply. However, its optics influenced the increase in agia, which appeared as a surcharge when exchanging for money with a base in gold. Considering that the increase in the share

81 J. Хаџи-Пешић, н. д., 182-186. 
also affected the convertibility of the dinar, the state marked the broadcasting institution as the main culprit. Based on the research of archival material and relevant literature, we conclude that the state is responsible for the growth of the bank, especially in the period from 1893 to 1903, with a constant budget deficit and unsettled political circumstances, but also the central bank with the amount of silver banknotes in circulation and hoarding of those in gold.

KEYWORDS: National Bank, bimetallism, agia, paper money, political and economic opportunities 